\title{
INSTITUTIONALIZATION OF STRATEGIC PARTNERSHIPS: COMPARATIVE ANALYSIS OF ESTABLISHED EUROPEAN UNION PARTNERSHIPS WITH THE UNITED STATES, JAPAN AND CANADA*
}

\author{
INSTYTUCJONALIZACJA PARTNERSTW STRATEGICZNYCH. \\ ANALIZA PORÓWNAWCZA UGRUNTOWANYCH \\ PARTNERSTW UNII EUROPEJSKIEJ ZE STANAMI \\ ZJEDNOCZONYMI, JAPONIĄ I KANADA
}
Agata Domachowska**๑), Karolina Gawron-Tabor***(0, Joanna Piechowiak-Lamparska**** (1)

\begin{abstract}
Strategic partnerships are nowadays one of the tools most willingly applied in foreign policy. The subject of the presented analysis is the institutionalization process of a strategic partnership understood as the functioning of certain norms and rules in a given relationship (expressed in the founding documents of partnerships) and the regularization of joint bodies and meeting formats. The aim of the article is a comparative analysis of institutional solutions applied in the European Union's strategic partnerships with its
\end{abstract}

\section{- ABSTRAKT -}

Partnerstwa strategiczne są współcześnie jednym z najchętniej stosowanych narzędzi w polityce zagranicznej. Przedmiotem przedstawionej analizy jest proces instytucjonalizacji partnerstwa strategicznego rozumiany jako funkcjonowanie w relacji określonych norm i zasad (wyrażonych w dokumentach fundacyjnych partnerstw) oraz regularyzacja wspólnych ciał i formatów spotkań. Celem artykułu jest analiza komparatystyczna rozwiązań instytucjonalnych stosowanych w partnerstwach strategicznych Unii Europejskiej

* This publication is a part of the scientific project "Strategic Partnership between a State and an International Organization: An Ideal Model” (the project was funded from the National Science Centre funds granted by decision No. UMO-2013/11/D/HS5/01260).

${ }^{* *}$ Nicolaus Copernicus University in Toruń, Faculty of Languages.

${ }_{* * *}$ WSB University in Toruń, Faculty of Finance and Management.

$* * * \star$ Nicolaus Copernicus University in Toruń, Faculty of Political Sciences and International Studies. 
established partners: the United States, Japan, and Canada. The results show that it is possible to identify a pattern of institutionalization process used by the European Union in its relations with strategic partners; they also reveal how great importance contemporary players in the international arena attach to institutionalization processes in their mutual relations.

Keywords: strategic partnership, institutionalization, the European Union, the United States, Japan, Canada z ugruntowanymi partnerami: Stanami Zjednoczonymi, Japonią oraz Kanadą. Wyniki wskazują, że można zidentyfikować wzorzec procesu instytucjonalizacji, który UE stosuje wobec swoich partnerów strategicznych, oraz uwidoczniają dużą wagę, jaką współcześni gracze na arenie międzynarodowej przykładają do procesów instytucjonalizacji wspólnych relacji.

Słowa kluczowe: partnerstwo strategiczne, instytucjonalizacja, Unia Europejska, Stany Zjednoczone, Japonia, Kanada

\section{INTRODUCTION}

Strategic partnerships are a tool used with growing frequency in the international arena to emphasize the importance and intensity of a relationship, usually between two subjects. Initially, it was an instrument used predominantly by states; however, in the twenty-first century it has been used with increasing frequency by international organizations such as NATO, the European Union (EU), and ASEAN. Strategic partnerships are an essential instrument of the European Union's foreign policy, particularly due to the wide range of possibilities they offer. Partnerships can be classified according to regions, position in a region, and aspirations as well as assumed international roles. The EU has established three partnerships with regions: 1) Latin America and the Caribbean, 2) Africa, the Mediterranean, and 3) the Middle East; two with international organizations: 1) the UN, and 2) NATO; as well as ten bilateral strategic partnerships with states: 1) Brazil, 2) Canada, 3) China, 4) India, 5) Japan, 6) Mexico, 7) Russia, 8) South Africa, 9) South Korea, and 10) the United States, but it withdrew from cooperation with Russia, i.a., due to the latter's annexation of Crimea. Following the former High Representative of the European Union for Foreign Affairs and Security Policy, Catherine Ashton, it is possible to distinguish bilateral partnerships with emerging leaders: China, India, Brazil, but also with traditional global powers with which the EU already enjoys established partnerships: the United States, Japan, and Canada (Ashton, 2010).

Current research is focused on discussing a tool/instrument of strategic partnerships used by the EU (Balfour, 2010; Gratius, 2011a; Grevi \& Khandekar, 
2011; Renard, 2010) or on analysing individual EU's partnerships formed both with states (the majority of studies concern China) and international organizations as well as individual regions. There is a lack of comparative studies and articles concerning the functioning of the EU's strategic partnerships. A rare exception is a work by Antoine Sautenet, who concentrates on juxtaposing the EU's new partnerships with states described as emerging leaders (Sautenet, 2011).

To help fill this gap in research, this article aims to apply comparative analysis of institutional solutions implemented in the EU's strategic partnerships with stable/established partners: 1) the US, 2) Japan, and 3) Canada. An interesting issue is a wide range of institutional solutions used by the $\mathrm{EU}$ which depend on aims the organization realizes not only with regard to a given partner but also with this partner. The comparable elements include norms and values determined in bilateral documents of the EU and its partner as well as joint bodies and meeting formats. The methods applied in the following article are comparative analysis, content analysis and the analysis of legal acts.

\section{THE TERM INSTITUTIONALIZATION}

In international relations there is no single definition of the term international institution. As Thomas Risse (2002, p. 605) points out: "There are at least as many definitions of (international) institutions as there are theoretical perspectives". Moreover, there are various forms of international institutions, whose scope seems to be systematically developing. At the beginning of the 1990s, Ole Wæver suggested that institutionalization concerns: 1) formal international or non-governmental international organizations; 2) international regimes as a negotiated order with clearly determined rules; and 3) international habits as not formalized and not hierarchical institutions (Wæver, 1992). As Marek Pietraś notices, Wæver's list definitely does not exhaust the variety of international institutions. Moreover, he points to diplomatic practices and integration processes as well as to new forms of international institutions - networks which create bonds (Pietraś, 2014).

The subject literature distinguishes five categories of international institutions: 1) institutions as formal organizations, 2) behaviour (practices), 3) rules, 4) norms, and 5) rules and norms (Duffield, 2007). Importantly, the change in understanding international institutions has been partially connected with the 
development of international relations as a scientific discipline (Martin \& Simmons, 1998).

Equating international institutions with international organizations took place in the $1950^{\mathrm{s}}$ and the $1960 \mathrm{~s}$. At that time, scientists used the term 'international institution' mainly with regard to formal international organizations, e.g., international financial institutions such as the International Monetary Fund and the World Bank (Duffield, 2007; Scott, 2013).

The change in understanding the term 'international institution' took place in the $1970^{\text {s }}$ and the $1980^{\text {s }}$ (Duffield, 2007; Martin \& Simmons, 1998). This process was influenced by the results of research on international regimes. Main theorists of international regimes such as Friedrich Kratochwil and John G. Ruggie (1986), Oran Young (1980), as well as Robert Keohane (1984) claimed that regimes should be understood as social institutions, which in turn required a detailed definition of the term 'institution'. Regime theory initiated the sociological approach to defining institution and equating it with its practices/behaviour. According to one of Young's first definitions, a social institution (a form of which is a political regime) is "recognized patterns of behavior or practice around which expectations converge" (Young, 1983, p. 93). However, equating institutions with behaviour is clearly a peculiar simplification. It is true that institutions undertake actions, but they also have a specific structure and principles of their practices, which are not taken into account in sociological definitions.

Regime theory also introduced equating institutions with rules or with a set of rules (Krasner, 1983). The rationalist - or rationalistic - conception of institutions seems to be the most widespread among researchers of international relations. As Lisa L. Martin and Beth A. Simmons notice, "most scholars have come to regard 'international institutions' as sets of rules meant to govern international behavior. Rules, in turn, are often conceived as statements that forbid, require, or permit particular kinds of actions" (Martin \& Simmons, 2013, p. 328). What can be evoked at this point are the definitions of institutions given by John Mearsheimer (1994), Robert Keohane (1989), and Wayne Sandholtz (2006). For example, Sandholtz presents the typology of institutions with regard to two dimensions of rules: "Since rules vary along two dimensions (formal-informal, specific-general), we can also classify international institutions according to the character of the rules that define them" (Sandholtz, 2006, p. 219).

In the 1980s, constructivists (in opposition to realists) began to equate institutions with norms. As Martha Finnemore and Kathryn Sikkink notice: "whereas constructivists in political science talk a language of norms, sociologists talk 
a language of 'institutions' to refer to these same behavioral rule" (Finnemore \& Sikkink, 1998, p. 891). In turn, Alexander Wendt defines institutions as "[...] made of norms and rules, which are ideational phenomena - 'shared mental models' - and as such, despite being objective social facts, they are firmly on the idealist side of the equation" (Wendt, 1999, p. 96). As John Duffield notices: "Within this literature, social institutions are generally viewed as consisting of norms or sets of norms [...] Norms, in turn, are usually defined by constructivists as socially shared expectations, understandings, or standards of appropriate behavior for actors with a given identity" (Duffield, 2007, p. 6). To describe institutions, constructivists very often use the term 'rules and norms', but they do not differentiate between them and use these two words interchangeably (Finnemore \& Sikkink, 1998). The essence of norms is that they are of intersubjective nature and must be internally adopted by the subject. For constructivists, institutions have an entirely cognitive character and do not exist without ideas and beliefs envisioning what the world should look like which are held by the subjects that create these institutions.

An approach combining both rules and norms in its understanding of institution is Duffield's definition: "international institutions should be defined as relatively stable sets of related constitutive, regulative, and procedural norms and rules that pertain to the international system, the actors in the system (including states as well as nonstate entities), and their activities" (Duffield, 2007, pp. 7-8). As the researcher points out, 'relatively stable' means that "an institution will exhibit at least some persistence, durability, and resilience in the face of changing circumstances", and 'related' is connected with the fact that "institutional elements are associated or connected in some meaningful way, such as by a functional or formal relationship" (Duffield, 2007, pp. 7-8). Within individual institutions, norms and rules may coexist or be present separately. It is important, however, that they perform specific functions: constitutive, regulative, and procedural. The procedural function of rules is related to establishing joint bodies and appropriate meeting formats.

Therefore, it can be assumed that the processes of institutionalization of partnerships are linked to the existence of specific norms and rules (clearly expressed in the founding documents of partnerships) as well as to establishing appropriate joint bodies and formats of their meetings. 


\section{THE EUROPEAN UNION'S STRATEGIC PARTNERSHIPS}

In the last 20 years, the European Union has developed numerous mechanisms and tools which aim at deepening relations with individual partners around the world. One of the examples of such mechanisms is strategic partnership.

The legal basis for establishing this kind of relationship can be found in the Treaty on the European Union (2008, Art. 21): “The Union shall seek to develop relations and build partnerships with third countries, and international, regional or global organisations which share the principles" of "democracy, the rule of law, the universality and indivisibility of human rights and fundamental freedoms, respect for human dignity, the principles of equality and solidarity, and respect for the principles of the United Nations Charter and international law".

However, no EU document provides a precise definition of a strategic partnership. What is more, the explicit terms 'strategic partnership' and 'strategic partner' do not appear in the Treaty on the European Union. They were first used by the EU in 1998 in the context of its relations with Russia: "The European Council had an in-depth discussion on the situation in Russia. It welcomes the Council's progress report on the development of a comprehensive EU policy towards Russia. It reaffirms Russia's importance as a strategic partner to the Union as demonstrated by the EU-Russia Summit in Vienna on 27 October. It stresses the Union's solidarity with Russia and its people during the present economic crisis. That crisis is multi-faceted. So too must be the response of the EU and the rest of the international community. The European Council underlines the Union's readiness to help Russia in overcoming the crisis through credible and sustained market-based reforms, while respecting urgent social needs, and a continued commitment to democracy including freedom of the media, the rule of law, and respect for human rights" (Vienna European Council, 1998).

Moreover, in 1999 these terms were used to describe the EU's relations with Latin America and the Caribbean, and then for a short time it went out of use (Renard, 2010). In 2003, the European Council adopted the European Security Strategy - A Secure Europe in a Better World (Council of the European Union, 2003), in which it described a particular kind of relations it had with individual states. For example, the United States was described as an 'irreplaceable partner'. The document also emphasized the necessity of developing strategic relations with such states as Canada, China, Japan, India and "all those who share our goals and values, and are prepared to act in their support". Moreover, strategic partnership with Russia was also confirmed: "We should continue to work for 
closer relations with Russia, a major factor in our security and prosperity. Respect for common values will reinforce progress towards a strategic partnership".

Currently, the EU declares that it has strategic partnerships with nine states: Brazil, Canada, India, China, Mexico, Japan, South Korea, South Africa and the United States. Since 2014, this group does no longer include Russia. This fact was confirmed by Federica Mogherini just after her being elected High Representative of the European Union for Foreign Affairs and Security Policy (EurActiv, 2014). In June 2015 that standpoint was also confirmed by the European Parliament, which passed a resolution on this matter: "[...] Russia, because of its actions in Crimea and in Eastern Ukraine, can no longer be treated as, or considered, a 'strategic partner'; points out that strategic partnerships must be based on mutual trust and respect for international law, which is based on democracy, state sovereignty and the freedom to choose internal constitutional order and foreign policy orientations, territorial integrity of the State, and respect for the rule of law, human rights, and the principles of international diplomacy and trade" (European Parliament, 2015a).

The EU does not establish strategic partnerships only with states: this kind of instrument is applied to deepen relationships also with other international organizations. The EU has now five strategic partnerships with groupings or international organizations: 1) Africa and the African Union, 2) the Mediterranean and Middle East, 3) Latin America and the Caribbean, 4) the United Nations, and 5) NATO. These partners differ as to their potential, importance and location. Considering these examples, it is difficult to determine distinguished criteria according to which the EU establishes strategic partnerships.

However, it is not of such a great importance as: "[i]t has been widely pointed out that the EU still has no single, concise definition of what a 'strategic' partner is. But this should not matter. SPs may not have great potential in enabling the EU to deepen cooperation on multilateralism with the big rising powers. But they can be useful as bilateral foreign policy tools across a larger number of partner states. They are most likely to offer added value to European foreign policy not in the largest but rather the second order powers. Instead of deepening commitments under a small and select number of SPs, the EU's priority goal should be to widen their geographical coverage" (Gratius, 2011a). 


\section{INSTITUTIONALIZATION OF THE EUROPEAN UNION'S PARTNERSHIPS}

\section{EU-United States}

In the 2003 European Security Strategy it is said: "The transatlantic relationship is irreplaceable. Acting together, the European Union and the United States can be a formidable force for good in the world. Our aim should be an effective and balanced partnership with the USA" (Council of the European Union, 2003). Similar importance of partnership was emphasized in the 2008 Report on the Implementation of the European Security Strategy: Providing Security in a Changing World, where it was stated that "[f] or Europe, the transatlantic partnership remains an irreplaceable foundation, based on shared history and responsibilities. The EU and NATO must deepen their strategic partnership for better co-operation in crisis management" (EU High Representative Javier Solana, 2008). The US was confirmed as the EU's key partner also in 2017 in a strategic document A Stronger Europe: A Global Strategy for the European Union's Foreign and Security Policy (European External Action Service, 2017).

Relations between the United States and the then European Communities actually began at the very moment of establishing the Communities. The United States was economically, politically and militarily engaged in the issues of Western Europe as well as supported integration processes starting with the end of the World War II (Lundestad, 2003), the best proof of which was the assistance provided within the Marshall Plan. Washington was the first capital to officially acknowledge the existence of the European Coal and Steel Community (ECSC). In response, the then High Authority (equivalent of the European Commission) sent its first foreign delegation to the United States in 1954. The delegation obtained full diplomatic status equal to an embassy of a national state in 1972 (Austermann, 2014). The US mission to the European Communities in Brussels was established in 1961. In 1973, the European Communities and the United States initiated information sharing practice regarding foreign policy, and in the 1980s, they ran more regular consultations in the domain of foreign policy (Ginsberg, 2001).

The relations between the United States and the European Union were not formalized until the 1990s. In 1990, the parties signed the Transatlantic Declaration, and in 1995 - the New Transatlantic Agenda and the Joint Action Plan. The next document which formalized the partnership was the 1998 Transatlantic Economic Partnership (TEP). In June 2013, the parties initiated negotiations on 
the EU-US Transatlantic Trade and Investment Partnership (TTIP). The negotiations were suspended after Donald Trump had been elected the president of the United States.

According to the US ambassador to the EU Stuart Eizenstat, the NTA was "the first time we have dealt comprehensively with the EU, not simply as a trade and economic organization, but as a partner in a whole array of foreign policy and diplomatic initiatives" (Frellesen, 2001, p. 333). For over 20 years, the parties have not signed a document which would comprehensively regulate functioning of the partnership. Both the TEP and the TTIP are mainly of economic nature.

In the NTA and the Joint Action Plan, the parties presented rules and norms which should govern the cooperation. The partners stated that following the values of democracy and free market, they would work towards creating transatlantic community as well as promoting stability and prosperity in Europe and around the world. What should serve this aim is cooperation in solving disputes on threatened territories, engagement in preventive diplomacy, providing development aid and humanitarian assistance as well as cooperation in international organizations (particularly within the UN). The parties also expressed their mutual support in combating organized crime, terrorism, massive migration, human trafficking, degradation of natural environment, as well as in promoting nuclear safety. The rule that also was to govern the partners' cooperation was the development of close economic relations (through creating a common transatlantic market) and world trade (through strengthening the WTO).

It should be emphasized that the United States and the European Union referred to similar norms when determining rules and aims of their cooperation. As Peterson and Pollack (2003) notice: "it remains clear that norms, values and culture bind the EU and the US together far more strongly that either party is 'bound' to any other part of the world" (p. 140). Citizens of the EU and the US perceive each other as those who belong to the same Western civilization with regard to the issues of democracy, human rights and market economy (Alcaro, Peterson \& Greco, 2016; Fuchs \& Klingemann, 2008). However, it should be noted that besides the sphere of declarations, there is a difference between the partners' approaches to norms and values, which is called a 'values gap' (Kagan, 2003; Peterson \& Pollack, 2003) and is related mainly to their different approaches to such issues as death penalty, environment conservation, abortion, religion and gun control. 
Institutions of cooperation started developing as early as in the 1990s. As Peterson and Steffenson (2009) notice, it was a "golden era in transatlantic institution building" (p. 26). At present, the parties have joint institutions and stable formats of meetings. According to Steffenson (2005), "the NTA institutions are designed to get experts talking and to get transgovernmental actors to assess how the EU and the US can cooperate under the 'mandate' of the NTA. The vast range of working groups, which are unparalleled in any other dialogue, identify areas where the EU and the US can coordinate efforts" (p. 66). Moreover, there are numerous informal interactions between the partners.

The most important decisions concerning the partnership are taken during the EU-US Summits, which are held at the highest level in troika meetings (President of the European Council, European Commission President, and the US President). Initially, they were organized twice a year, and since 2000 - once a year. As Steffenson notices (2005): "As an event, the summit creates the impulse to produce deliverables. In short it is a decision 'making' forum" (p. 65). Moreover, there are meetings held at the ministerial level, and two times a year - at the EU Foreign Ministers and US Secretary of State level.

The partnership established also joint institutions, among which an important role is played by the Senior Level Group (SLG) at the level of US Undersecretary of State and EU Commission Director General to oversee implementation of the NTA. According to Steffenson (2005): "In what resembles a pyramid structure the SLG connects the 'expert' level and the political level. It pulls the NTA process together" (p. 66). In the institutional pyramid at the lower level, there is a working group tasked with implementation of the NTA (NTA Task Force) that works at the director level to facilitate exchanges at the operational level. Additionally, there are task-specific working groups (including those dealing with human trafficking and terrorism). Organization of ministerial meetings is the responsibility of Troika working groups.

Having in mind how important the economic issues are for the cooperation, the parties established the Transatlantic Economic Council (TEC) (which substituted in 2007 the former Transatlantic Economic Partnership). The TEC is presented as a "political body to oversee and accelerate governmentto-government cooperation with the aim of advancing economic integration between the European Union and the United States of America" (Romero, 2012, p. 93). The partners also formed the US-EU Energy Council. The Council meets annually and reports to the wider EU-US summit. The Council is chaired by the EU High Representative/Vice President, the EU Vice President for Energy Union, 
the EU Commissioner for Climate and Energy, the US Secretary of State and the US Secretary of Energy. A representative from the rotating EU Presidency also participates (EU-US Summit, 2009).

Meetings held in the dialogue format are also important. First of all, they include a Transatlantic Legislators Dialogue (TLD), involving regular exchanges between the European Parliament (EP) and the US House of Representatives. The dialogue between EU and US legislators is the "longest and most intensive dialogue" in the history of the European Parliament (European Parliament Liaison Office with US Congress, 2015). Moreover, there are series of people-to-people dialogues, including the Transatlantic Business Dialogue and the Transatlantic Consumer Dialogue, Transatlantic Donors Dialogue, Transatlantic Business Dialogue Transatlantic Labour Dialogue, Transatlantic Environmental Dialogue, Transatlantic Education Dialogue. Another important series of dialogues related to the domain of economic regulation and cooperation include, first of all, Innovation Dialogue, Insurance Dialogue, and Financial Markets Regulatory Dialogue.

It should be noted that the aforementioned bodies and meeting formats are only the most important ones. Working groups and ministerial meetings are organized in all cooperation domains. Moreover, the parties have a number of informal contacts. As Mark A. Pollack says: "interviews with practitioners from the United States and the European Union reveal that considerable informal cooperation takes place across virtually every considerable area of US and EU regulation, with little attention from the press, scholars, or political actors" (Peterson \& Pollack, 2003, p. 34).

\section{EU-Japan}

The official relations between the EU (at that time, the European Economic Community, EEC) and Japan were initiated in 1959, when the Japanese prime minister visited Brussels and the Japanese ambassador received accreditation to the organization (Borucińska, 2018, p. 16; de Prado Yepes, 2017, p. 435)1. Until the end of the Cold War, the relations were based mainly on cooperation in the economic domain (de Prado Yepes, 2014, p. 13) and were characterized by numerous trade disputes resulting from "Japan's growing importance in global economy and its export expansion. At that time, the EEC states perceived Japan

\footnotetext{
1 European delegation to Japan was established in 1974.
} 
as a rapidly growing competitor in important sectors of economy" (Mazur, 2016, p. 7). Only after signing the 1991 Joint Declaration on Relations between the European Community and Its Member States and Japan did the partners start slowly establishing cooperation in such domains as keeping peace, development and stability in the world (Suzuki, 2017, p. 877). The changes which took place in the international arena, mainly after the $9 / 11$ attacks, also played an important role in rapprochement between the EU and Japan - particularly with regard to new challenges in international security (Tsuruoka, 2012, p. 71). When assessing the current state of cooperation between the parties, Shigekazu Kusune (2016) notices that "Japan cannot alone accomplish many things. It must work together with another partner. Which nation or region is suitable as a partner for Japan? Is it America or China or Russia? My answer is the EU. Japan and the EU have advanced technology, financial and human resources. Japan and the EU are soft powers which have won trust and respect in the world" (p. 104).

Formalization of the relationship happened in 1991, when the parties signed the Joint Declaration on Relations between the European Community and Its Member States and Japan known as the Hague Declaration. Ten years later, Japan and the EU signed the Shaping Our Common Future: An Action Plan for European Union-Japan Cooperation (Ministry of Foreign Policy of Japan, 2001). On 17 July 2018, during the $25^{\text {th }}$ EU-Japan Summit in Tokyo, the partners signed another two key agreements - the EU-Japan Strategic Partnership Agreement (SPA) and the Free Trade/Economic Partnership Agreement (EPA) (European Commission, $2017)^{2}$.

The adopted Declaration (1991) determined both rules and norms underpinning their cooperation: "The European Community and its member States on the one part and Japan on the other part, conscious of their common attachment to freedom, democracy, the rule of law and human rights; affirming their common attachment to market principles, the promotion of free trade and the development of a prosperous and sound world economy; recalling their increasingly close ties and acknowledging growing world-wide interdependence and, ,

2 In the meantime, from 2001 to 2018, Japan and the EU have signed also four other important agreements: The EU-Japan Mutual Recognition Agreement (1 January 2002), Agreement on Co-operation on Anti-competitive Activities (16 June 2003), The Science and Technology Agreement (30 November 2009), The Agreement on Co-operation and Mutual Administrative Assistance (1 February 2008). Retrieved from: http://ec.europa.eu/trade/policy/countries-and-regions/countries/ japan/index_en.htm; see more: Ministry of Foreign Policy of Japan, 2018, https://www.mofa.go.jp/ ecm/ie/page4e_000875.html. 
consequently, the need for heightened international co-operation; affirming their common interest in security, peace and stability of the world" (Joint Declaration on Relations..., 1991, p. 1). They were also repeated in the EU-Japan Strategic Partnership Agreement (2018): "Reaffirming their commitment to the common values and principles, in particular democracy, the rule of law, human rights and fundamental freedoms, which constitute the basis for their deep and long-lasting cooperation as strategic partners" and "Conscious, in this regard, as like-minded global partners, of their shared responsibility and commitment to setting up a just and stable international order in accordance with the principles and purposes of the Charter of the United Nations, and to achieve peace, stability and prosperity of the world as well as human security" (Ministry of Foreign Policy of Japan, 2018a).

The partners have been developing institutions of cooperation since the 1980s, when in 1984 the $1^{\text {st }}$ EC-Japan Ministerial Meeting was held (EU-Japan 2018). The most important agreements are usually signed during annual EUJapan Summits (Borucińska, 2018, p. 16). They have been organized since 1991. The $25^{\text {th }}$ EU-Japan Summit was held in July 2018. Other formats of meetings include the Japan-EU Foreign Ministers' Meeting, which should be organized twice a year (European Commission, 2018; Ministry of Foreign Policy of Japan, 2015; Wright, 2013, p. 164). Moreover, there are exchanges of parliamentary delegations, initiated as early as in 1978 (de Prado Yepes, 2014, p. 26; Gilson, 2000, p. 177), while in 2018 the partners organized the $38^{\text {th }}$ meeting between members of their parliaments (European Parliament, 2018).

According to the EU-Japan Strategic Partnership Agreement (2018, Art. 42), the parties established Joint Committee - a body tasked with coordinating cooperation development, ensuring appropriate implementation of specific points of the agreement, and analysing possibilities of extending the EU-Japan relations into domains net included in the adopted document. The Committee is to meet at least annually in Tokyo or Brussels, and its decisions are based on consensus.

The partners also organized meetings at the Japan-EU High-level Consultations (Ministry of Foreign Policy of Japan, 2014). There are also important meetings in the dialogue format, the most important being The ICT Policy Dialogue, The EU-Japan bilateral cyber dialogue, Space Dialogue, The EU-Japan Industrial Policy Dialogue, EU-Japan Steel Contact Group Meeting, Industrial Dialogue on Railways, High Level Dialogue on the Environment, High Level Bilateral Dialogue on Climate Change, Energy Dialogue, Agricultural Policy Dialogue, Food Safety Dialogue, High Level Dialogue on Fisheries and Maritime Affairs, 
Macroeconomic Dialogue, High Level Meeting on Financial Issues, Transport Policy Dialogues, Competition Policy Dialogue (Delegation of the European Union to Japan, 2017), Japan-EU Regulatory Reform Dialogue, Japan-EU Development Cooperation, the Japan-EU Industrial Policy, Industrial Cooperation Dialogue, the Japan-EU High Level Consultation on Financial Affairs, and the Japan-EU Economic Consultations (Ministry of Foreign Policy of Japan, 2004, p. 1). Moreover, in 2010 the parties established the EU-Japan Joint Customs Cooperation Committee (JCCC) (Delegation of the European Union to Japan, 2017). It should be emphasized that cooperation between the partners is also strengthened by meetings in various formats, i.a., at different ministerial-level or within working groups (EU-Japan Troika Working Group) (Yoon \& Suh, 2013, p. 417).

\section{The EU-Canada}

Relations between the European Union and Canada exemplify a stable, longstanding and effective partnership between an international organization and a state. Historically, the process of rapprochement began in the 1950s; however, initially it concerned only the economic sphere. Political dialogue in the relations between Brussels and Ottawa was gradually developing, and in 1972 the parties held consultations which formed the basis for further activities. In 1976, the European Economic Community (EEC) signed with Canada the Framework Agreement for Commercial and Economic Cooperation, which was the first formal agreement of this type between the EEC and an industrialized state. The partners undertook "to develop and diversify their reciprocal commercial exchanges and to foster economic co-operation" on the basis of "common heritage, special affinity and shared aspirations" (Framework Agreement..., 1976). Undoubtedly, it was a significant formal step in their mutual relations, which was also proved by establishing a joint body, i.e., the Joint Cooperation Committee, which met regularly once a year. Also, in 1976, the EEC established its diplomatic mission in Ottawa. It was the third EEC diplomatic mission in the world, which proves Canada's high status and priority in the bilateral relations.

In 1990, the EEC and Canada signed the Declaration on Transatlantic Relations, which significantly extended the cooperation scope. It was the next important stage as it introduced regularization of mutual contacts in the form of regular meetings - summits (the partners planned annual meetings between the President of the European Council, the President of the Commission, and the 
Prime Minister of Canada) as well as meetings at ministerial level (the partners planned semi-annual meetings between the President of the Council of the European Communities with the Commission and the Secretary of State for External Affairs of Canada; annual meetings between the Commission and the Canadian Government). The declaration also covered cooperation in additional areas, which previously had not been the subject of the EU-Canada relations, focused on economic cooperation. First of all, it should be emphasized that the partners set mutual goals concerning cooperation for development of democracy, prevention and settlement of disputes around the world, support for developing states and stabilization of international economic relations. On numerous occasions, the partners referred to common values, stating that their relationship was "bonded by their common heritage and close historical, political, economic and cultural ties" (Transatlantic Declaration on EC-US Relations, 1990). All this helped determine the array of challenges that the partners decided to jointly face: combating and prevention of terrorism, combating and prevention of international crime, non-proliferation of weapons of mass destruction, protection of natural environment, control on migration and flow of refugees.

The next stage of the relationship was signing the Canada-EU Joint Political Declaration and Action Plan in 1996 during the summit in Ottawa. The Action Plan extended the areas of cooperation and determined them more precisely, first of all due to the possibility and will to tighten the partnership. It was agreed that the tightened cooperation should concern four main domains: economic and trade relations, foreign policy and security issues, transnational issues, and fostering links. Apart from the issues regarding bilateral relations between the EU and Canada, the agenda also included such matters as multilateral relations within the framework of international organizations and forums, regional problems and conflicts, and transatlantic security. Importantly, in the process of achieving the goals the partners should be "mindful of the ties of history, tradition, culture, and kinship that bind us, and of our community of values" (Canada-EU Joint Political Declaration and Action Plan, 1996). The declaration became the basis for concluding detailed bilateral agreements on specific issues. During the next summit in Ottawa in 2004, in order to uphold the processes of rapprochement, the partners announced the Canada-EU Partnership Agenda, whose aim was to establish a further action plan. First of all, the parties indentified priorities of their cooperation as follows: advancing international security and effective multilateralism, further global economic prosperity, deepening cooperation on justice and home affairs, addressing 
global and regional challenges, as well as fostering closer links between the people of the EU and Canada.

The European Union and Canada strengthened their cooperation in the domain of security and countering terrorism, organised international crime and weapons of mass destruction proliferation also in response to the 9/11 terrorist attack on the United States. The joint statements after the summits in Ottawa in 2001 and in Toledo in 2002 regarded such issues as financing terrorist organisations and international crime groups as well as the organisation of crisis response operations. As a result, Canada participated in European Union Force in Bosnia and Herzegovina (EUFOR Althea) and EU Police Missions in Afghanistan (EUPOL Afghanistan); moreover, the partners signed, i.a., the Agreement between the European Union and Canada Establishing a Framework for the Participation of Canada in the European Union Crisis Management Operations (2005).

The strategic partnership between the EU and Canada was formally established in 2016 within the Strategic Partnership Agreement (SPA). According to the agreement, the Joint Ministerial Committee, co-chaired by the Minister of Foreign Affairs of Canada and the High Representative of the Union for Foreign Affairs and Security Policy, substituted the Transatlantic Dialogue. The parties also established the Joint Cooperation Committee, whose task is to monitor the development of strategic relations between the partners and to give recommendations on improving effectiveness, efficiency and synergy. Moreover, the plans included regular meetings of both bodies and the possibility for establishing new ones if there was a need and it was justified by the development of EU-Canada relations. According to the parties' declaration, the SPA is based on common values and norms and "the Parties shall implement this Agreement based on shared values, the principles of dialogue, mutual respect, equal partnership, multilateralism, consensus and respect for international law" (SPA, p. 3). The agreement included tightening the cooperation and the development of bilateral relations also within the framework of multilateral formats.

Also, in 2016, apart from the SPA, the partners concluded the Comprehensive Economic and Trade Agreement (CETA) - a new trade agreement between the EU and Canada. This was an important step towards improving economic cooperation. The CETA was to reduce duties by $98 \%$ and to introduce regulations on trade and services. The agreement is particularly important due to the position the partners have with regard to each other in the area of trade (in 2017, the EU was Canada's second largest trade partner, and Canada was the EU's tenth international trade partner; European Parliament, 2018). 
The European Union and Canada are for each other important strategic partners. This is proved not only by signed agreements and declarations such as the SPA and the CETA but also aspirations for a high level of regularization and an array of common norms and values. The EU states that "Canada is one of the closest and longest-standing partners of the European Union. Our common democratic values, responsibility to defend human rights, and strong commitment to multilateralism, the rules-based international order and free trade define our relationship" (European Union External Action, 2018).

\section{CONCLUSIONS}

The aim of the article was a comparative analysis of institutional solutions applied in the EU's strategic partnerships with stable/established partners: the United States, Japan, and Canada. The compared elements included norms and values described in bilateral documents as well as joint bodies and meeting formats. The results of the analysis of the three case studies show high level of institutionalization of strategic partnerships. In all cases investigated here, the elements necessary for determining the level of institutionalization are present (see: Table 1).

Table 1. The presence of elements of institutionalization in the EU's established partnerships

\begin{tabular}{|l|c|c|c|}
\hline $\begin{array}{l}\text { Elements of } \\
\text { institutionalization }\end{array}$ & EU-US & EU-Japan & EU-Canada \\
\hline Norms and values & $\checkmark$ & $\checkmark$ & $\checkmark$ \\
\hline Joint bodies & $\checkmark$ & $\checkmark$ & $\checkmark$ \\
\hline Set formats of meetings & $\checkmark$ & $\checkmark$ & $\checkmark$ \\
\hline
\end{tabular}

Source: Own research.

The presented results lead to two basic conclusions. First, there is a visible pattern which is followed by the European Union in the process of institutionalization of its relations with the established partners. It means that institutionalization understood as a process aimed at strengthening relations is repeatable and concerns numerous formal partnerships of the EU. Also, the research conducted within the SPG project shows and confirms that the European Union created 
a particular pattern of an institutional path which a state follows in the process of tightening partnership bonds. Therefore, states which formalize their relations with the EU can expect gradual completion of subsequent stages of institutionalization and thus should be prepared for them.

The second conclusion of a more general nature shows a great role which contemporary players in the international arena attach to institutionalization processes in their mutual relations. The analysis covered the European Union (one of the most influential international organizations of an intergovernmental character), the United States (a global superpower), Japan and Canada (regional powers) - the subjects which play important roles in the international system. What can be also observed is that over time, institutionalization processes are deepening, and the subsequent cooperation domains are regularized since regularization means certain predictability, secure sequence of events and control over the course of processes.

The presented results indicate that institutionalization of strategic partnerships can constitute an important research question. Undoubtedly, it would be a good idea to extend the array of analyzed elements or research the level of their intensity and not only their presence. Strategic partnerships are relations of a unique nature, often with their very particular goals and intentions. It is even more interesting that the process of institutionalization is similar in the case of global superpowers and less important regional powers.

\section{ReFERENCES:}

Agreement between the European Union and Canada Establishing a Framework for the Participation of Canada in the European Union Crisis Management Operations Declarations (2005). Retrieved from: https://eur-lex.europa.eu/legal-content/EN/ TXT/?uri=CELEX\%3A22005A1201\%2801\%29.

Alcaro, R., Peterson, J., \& Greco, E. (eds.) (2016). The West and the Global Power Shift:

Transatlantic Relations and Global Governance. New York: Palgrave Macmillan.

Ashton, C. (2010). Europe and the World. Speech/10/378, Megaron "The Athens Concert Hall”, Athens, 8 July 2010. Retrieved from: http://europa.eu/rapid/press-release_ SPEECH-10-378_en.htm.

Austermann, F. (2014). European Union Delegations in EU Foreign Policy: A Diplomatic Service of Different Speeds. New York: Palgrave Macmillan.

Bache, I. (2010). Partnership as an EU policy instrument: a political history. West European Politics, 33(1), 58-74. DOI: 10.1080/01402380903354080. 
Balfour, R. (2010). EU Strategic Partnerships: Are They Worth the Name? European Policy Centre Commentary. September 15. Retrieved from: http://www.epc.eu/ documents/uploads/pub_1145_eu_strategic_partnerships_-_are_they_worth_ the_name.pdf.

Barry, D. (2004). Toward a Canada-EU partnership? In: P.M. Crowley (ed.), Crossing the Atlantic: Comparing the European Union and Canada (pp. 35-58). London \& New York: Routledge.

Borucińska, I. (2018). The European Union and Japan towards Strategic Partnership Agreement and Economic Partnership Agreement. Regional Formation and Development Studies, 25(2), 14-23. DOI: 10.15181/rfds.v25i2.1741.

Canada-EU Joint Political Declaration and Action Plan (1996). Retrieved from: http:// www.canadainternational.gc.ca/eu-ue/commerce_international/joint_politicalpolitique_conjointe.aspx?lang=eng.

Canada-EU Partnership Agenda (2004). Retrieved from: http://www.canadainternational.gc.ca/eu-ue/commerce_international/partnership-partenariat. aspx?lang=eng.

Comprehensive Economic and Trade Agreement (CETA) between Canada, of the one Part, and the European Union and Its Member States, of the Other Part (2016). Retrieved from: https://eur-lex.europa.eu/legal-content/EN/TXT/PDF/?uri=CELEX:22017 A0114(01)\&from $=$ EN.

Council of the European Union (2003). European Security Strategy - a Secure Europe in a Better World. Retrieved from: https://www.consilium.europa.eu/media/30823/ qc7809568enc.pdf.

Delegation of the European Union to Japan (2017). Policy Dialogues. Retrieved from: https://eeas.europa.eu/delegations/japan/19237/policy-dialogues_en.

de Prado Yepes, C. (2014). Prospects for the EU-Japan Strategic Partnership: A Global Multi-Level and SWOT Analysis. Florence \& Tokyo: EU-Japan Centre for Industrial Cooperation. Retrieved from: https://www.eu-japan.eu/sites/default/files/publications/docs/eujpstrategicpartnership.pdf.

de Prado Yepes, C. (2017). Towards a Substantial EU-Japan Partnership. European Foreign Affairs Review, 22(4), 435-454.

Duffield, J. (2007). What Are International Institutions? International Studies Review, 9(1), 1-22. DOI: 10.1111/j.1468-2486.2007.00643.x.

EU High Representative Javier Solana (2008). Report on the Implementation of the European Security Strategy: Providing Security in a Changing World. December 11. Retrieved from: https://www.consilium.europa.eu/uedocs/cms_data/docs/ pressdata/en/reports/104630.pdf.

EU-Japan (2018). EU Japan Summit Meetings. Retrieved from: https://eu-japan.com/ eu-japan-agreements/eu-japan-summit-meetings/.

EurActiv (2014). Mogherini: Russia Is No Longer the EU's Strategic Partner. Retrieved from: http://www.euractiv.com/section/global-europe/news/mogherini-russia-isno-longer-the-eu-s-strategic-partner/. 
European Commission (2017). EU-Japan Economic Partnership Agreement: Texts of the Agreement. Retrieved from: http://trade.ec.europa.eu/doclib/press/index. $\mathrm{cfm}$ ? id $=1684$.

European Commission (2018). Paving the Way. Retrieved from: http://europa.eu/rapid/ press-release_MEMO-96-92_en.htm.

European External Action Service (2017). Shared Vision, Common Action. A Stronger Europe: A Global Strategy for the European Union's Foreign and Security Policy. Retrieved from: https://publications.europa.eu/en/publication-detail/-/ publication/3eaae2cf-9ac5-11e6-868c-01aa75ed71a1.

European Parliament (2015). Russia Is No Longer a Strategic Partner of the EU, Say MEPs. Retrieved from: http://www.europarl.europa.eu/news/en/pressroom/20150604IPR62878/russia-is-no-longer-a-strategic-partner-of-the-eu-saymeps.

European Parliament (2015a). European Parliament Resolution of 10 June 2015 on the State of EU-Russia Relations. Retrieved from: http://www.europarl.europa.eu/sides/ getDoc.do?pubRef=-//EP//TEXT+TA+P8-TA-2015-0225+0+DOC+XML+V0// EN.

European Parliament (2018). 38 $8^{\text {th }}$ EU-Japan Interparliamentary Meeting, May 2018 Tokyo \& Hiroshima. Retrieved from: http://www.europarl.europa.eu/delegations/ en/d-jp/activities/inter-parliamentary.

European Parliament (2018a). Transatlantic Relations: USA and Canada. Retrieved from: http://www.europarl.europa.eu/factsheets/en/sheet/174/stosunki-transatlantyckie-usa-i-kanada.

European Parliament. Liaison Office with U.S. Congress. (2015). EU-US Relations. Retrieved October 21, 2017 from: http://www.europarl.europa.eu/unitedstates/ en/eu-us-relations.

European Union External Action (2018). EU-Canada Relations. Retrieved from: https:// eeas.europa.eu/headquarters/headquarters-homepage_en/13530/EU-Canada\%20 relations.

EU-US Summit. (2009). U.S EU Energy Council. Annex 2. Retrieved April 21, 2018 from: https://ec.europa.eu/energy/sites/ener/files/documents/2009_energy_council_joint_press_statement.pdf.

Finnemore, M., \& Sikkink, K. (1998). International Norm Dynamics and Political Change. International Organization, 52(4), 887-917.

Framework Agreement for Commercial and Economic Cooperation between the European Communities and Canada (1976). Retrieved from: http://ec.europa.eu/world/agreements/prepareCreateTreatiesWorkspace/treatiesGeneralData.do?step=0\&redirec $\mathrm{t}=$ true $\&$ treatyId $=267$.

Frellesen, T. (2001). Processes and Procedures in EU-US Foreign Policy Co-operation: From the Transatlantic Declaration to the New Transatlantic Agenda. In: E. Philippart, \& P. Winand (eds.), Ever Closer Partnership. Policy-making in EU-US Relations (pp. 313-350). New York \& Oxford: Peter Lang. 
Fuchs, D., \& Klingemann, H.D. (2008). American Exceptionalism or Western Civilization. In: J. Anderson et al. (eds.), The End of the West? Crisis and Change in the Atlantic Order (pp. 247-262). Ithaca NY: Cornell University Press.

Gilson, J. (2000). Japan and the European Union: A Partnership for the Twenty-First Century? New York: Springer.

Ginsberg, R.H. (2001). The European Union in International Politics: Baptism by Fire. Lanham, Boulder, New York \& Oxford: Rowman \& Littlefield.

Gratius, S. (2011). Can EU Strategic Partnerships Deepen Multilateralism? Fride Working Paper, 109. Retrieved from: http://fride.org/download/WP109_EU_Strategic_Partnerships.pdf.

Gratius, S. (2011a). The EU and the 'Special Ten': Deepening Or Widening Strategic Partnerships? Madrid: La Fundación para las Relaciones Internacionales y el Diálogo Exterior. Retrieved from: http://fride.org/descarga/PB_76_Strategic_Partnerships_Eng.pdf.

Grevi, G., \& Khandekar, G. (2011). Mapping EU Strategic Partnerships. Madrid: La Fundación para las Relaciones Internacionales y el Diálogo Exterior. Retrieved from: http://www.fride.org/publication/956/mapping-eu-strategic-partnerships.

Joint Declaration on Relations between the European Community and Its Member States and Japan (1991). Retrieved from: http://eeas.europa.eu/archives/docs/japan/docs/ joint_pol_decl_en.pdf.

Kagan, R. (2003). Of Paradise and Power: America and Europe in the New World Order. New York: Alfred A. Knopf.

Keohane, R.O. (1984). After Hegemony: Cooperation and Discord in the World Political Economy. Princeton: Princeton University Press.

Keohane, R.O. (1989). Neoliberal Institutionalism: A Perspective on World Politics. In: R.O. Keohane (ed.), International Institutions and State Power: Essays in International Relations Theory (pp. 1-20). Boulder: Westview Press.

Krasner, S.D. (1983). Structural Causes and Regime Consequences: Regimes as Intervening Variables. In: S.D. Krasner (ed.), International Regimes (pp. 1-22). Ithaca: Cornell University Press [reprinted from: International Organization, 36(2): International Regimes (Spring, 1982), pp. 185-205].

Kratochwil, F., \& Ruggie, J.G. (1986). International Organization: A State of the Art on an Art of the State. International Organization, 40(4), 753-775.

Kusune, S. (2016). The Relationship between Japan and the EU. Journal of Global Tourism Research, 1(2), 101-104.

Lundestad, G. (2003). The United States and Western Europe since 1945: From "Empire" by Invitation to Transatlantic Drift. Oxford: OUP Oxford.

Martin, L.L., Simmons, B.A. (1998). Theories and Empirical Studies of International Institutions. International Organization, 52(4), 729-757.

Martin, B.A., \& Simmons, L.L. (2013). International Organizations and Institutions. In: W. Carlsnaes, T. Risse-Kappen, \& B.A. Simmons (eds.), Handbook of International Relations [2 ${ }^{\text {nd }}$ ed.] (pp. 326-351). London, Thousand Oaks \& New Delhi: SAGE Publications. 
Mazur, G. (2016). Interesy ofensywne unijnych przedsiębiorstw w kontekście negocjowanej umowy o strefie wolnego handlu UE-Japonia, Unia Europejska.pl, 3, 6-18.

Mearsheimer, J.J. (1994). The False Promise of International Institutions. International Security, 19(3), 5-49. DOI: 10.2307/2539078.

Ministry of Foreign Policy of Japan (2001). An Action Plan for EU-Japan Cooperation. European Union - Japan Summit. Brussels. Retrieved from: https://www.mofa.go.jp/ region/europe/eu/summit/action0112.html.

Ministry of Foreign Policy of Japan (2004). Cooperation Framework for Promotion of Japan-EU Two-Way Investment. Retrieved from: https://www.mofa.go.jp/region/ europe/eu/summit/coop0406.pdf.

Ministry of Foreign Policy of Japan (2014). Japan-EU High-level Consultations. Retrieved from: https://www.mofa.go.jp/region/europe/eu/dialogue/hlc.html.

Ministry of Foreign Policy of Japan (2015). Japan-EU Foreign Ministers' Meeting. Retrieved from: https://www.mofa.go.jp/region/europe/eu/dialogue/fm.html.

Ministry of Foreign Policy of Japan (2018). Japan-EU Economic Partnership Agreement (EPA). Retrieved from: https://www.mofa.go.jp/ecm/ie/page4e_000875.html.

Ministry of Foreign Policy of Japan (2018a). Strategic Partnership Agreement between the European Union and Its Member States, of the One Part, and Japan, of the Other Part. Retrieved from: https://www.mofa.go.jp/files/000381942.pdf.

Peterson, J., \& Pollack, M.A. (2003). Europe, America, Bush: Transatlantic Relations in the Twenty-First Century. London \& New York: Routledge.

Peterson, J., \& Steffenson, R. (2009). Transatlantic Institutions: Can Partnership Be Engineered? The British Journal of Politics \& International Relations, 11(1), 25-45.

Pietraś, M. (2014). Teoria i praktyka reżimów międzynarodowych. In: K. Kącka (ed.), Stosunki Międzynarodowe. Wokół zagadnień teoretycznych (pp. 13-68). Toruń: Wydawnictwo UMK.

Renard, T. (2010). EU Strategic Partnerships: Evolution of a Concept, from Amsterdam to Lisbon. EU-China Observer, 5, 16-22.

Renard, T. (2010a). Strategy Wanted: The European Union and Strategic Partnerships. Security Policy Brief, 13, 1-7. Retrieved from: https://core.ac.uk/download/ pdf/148853114.pdf.

Renard, T. (2011). The Treachery of Strategies: A Call for True EU Strategic Partnerships (Egmont Papers-45) (Vol. 45). Brussels: Academia Press.

Risse, T. (2002). Constructivism and International Institutions: Toward Conversations Across Paradigms. In: I. Katznelson, \& H.V. Milner (eds.), Political Science: The State of the Discipline (pp. 597-623). New York: Norton.

Romero, L.D. (2012). Europe and the USA: Diagnosis of the Trans-Atlantic Relationship in the Twenty First Century. In: Boening, A.B., Romero, L.D., Hernández, J.R.G., del Miño, P.G., Helwig, N., Lannoo, K., ... \& Yilmaz, B. The EU as a Global Player. (pp. 89-100). Madrid: Fundación Univ. San Pablo CEU.

Sandholtz, W. (2006). Globalization and the Evolution of Rules. In: R. Little, \& M. Smith (eds.), Perspectives on World Politics (pp. 217-226). London \& New York: Routledge. 
Sautenet, A. (2011). The EU's Strategic Partnerships with Emerging Powers: Institutional, Legal, Economic and Political Perspectives. In: T. Rénard, \& S. Biscop (eds.), The European Union and Emerging Powers in the 21 $1^{\text {st }}$ Century: How Europe Can Shape a New Global Order (pp. 123-146). London \& New York: Routledge.

Scott, W.R. (2013). Institutions and Organizations: Ideas, Interests, and Identities. Los Angeles, London \& New Delhi: Sage Publications.

Steffenson, R. (2005). Managing EU-US relations: Actors, Institutions and the New Transatlantic Agenda. Manchester \& New York: Manchester University Press.

Strategic Partnership Agreement between the European Union and Its Member States, of the One Part, and Canada, of the Other Part (2016). Retrieved from: https://eur-lex. europa.eu/legal-content/EN/TXT/PDF/?uri=CELEX:22016A1203(03)\&from=EN.

Suzuki, H. (2017). The New Politics of Trade: EU-Japan. Journal of European Integration, 39(7), 875-889. DOI: 10.1080/07036337.2017.1371709.

Transatlantic Declaration on EC-US Relations. (1990). Retrieved May 10, 2016 from: http://www.europarl.europa.eu/cmsdata/124320/trans_declaration_90_en.pdf.

Treaty on European Union (2008). Retrieved from: https://eur-lex.europa.eu/legalcontent/PL/TXT/?uri=celex\%3A12012M\%2FTXT.

Tsuruoka, M. (2012). The Potential for EU-Japan Political and Security Cooperation: A Japanese Perspective. In: J. Szczudlik-Tatar, \& A. Gradziuk (eds.), Japan and the European Union: Challenges and Cooperation in Times of Crisis (pp. 71-82). Warszawa: PISM.

Vienna European Council (1998). Presidency Conclusions. December 11-12. Retrieved from: https://www.consilium.europa.eu/uedocs/cms_data/docs/pressdata/en/ ec/00300-R1.EN8.htm.

Wæver, O. (1992). International Society - Theoretical Promises Unfulfilled? Cooperation and Conflict, 27(1), 97-128.

Wendt, A. (1999). Social Theory of International Politics. Cambridge: Cambridge University Press.

Wright, R. (2013). 1996-2000: Consolidating a Mature Relationship. In: J. Keck, D. Vanoverbeke, \& F. Waldenberger (eds.), EU-Japan Relations, 1970-2012: From Confrontation to Global Partnership (pp. 175-189). London \& New York: Routledge. Yoon, S.J., \& Suh, J.J. (2013). Nuclear Non-Proliferation. In: T. Christiansen, E. Kirchner, \& P. Murray (eds.), The Palgrave Handbook of EU-Asia Relations (pp. 406-420). London: Palgrave Macmillan.

Young, O.R. (1980). International Regimes: Problems of Concept Formation. World Politics, 32(3), 331-356.

Young, O.R. (1983). Regime Dynamics: The Rise and Fall of International Regimes. In: S.D. Krasner (ed.), International Regimes (pp. 93-114). Ithaca: Cornell University Press [reprinted from: International Organization, 36(2): International Regimes (Spring, 1982), pp. 277-297]. 